\title{
ESTIMATION OF SURFACE RUNOFF USING GEOSPATIAL TECHNOLOGY KOMBAI MICRO WATERSHED - A CASE STUDY
}

\author{
Ramasubramaniam K. ${ }^{1}$, Pugazhendi V. ${ }^{2}$, Anitha A. ${ }^{3}$, Dawn S S ${ }^{4}$ \\ ${ }^{1}$ Research Scholar, University of Madras, Chennai, India \\ ${ }^{2}$ Tamil Nadu Water and Drainage Board, Chennai, India \\ ${ }^{3,4}$ Department Chemical Engineering, Sathyabama University, Rajiv Gandhi Road, Chennai, India \\ E-mail : purenviro@eth.net
}

\begin{abstract}
Geospatial technology is being widely used for the assessment of natural resources. The present paper deals with the usage of geospatial technology for the estimation of surface runoff on a watershed basis. The Kombai micro watershed of Vaigai basin covers $64.08 \mathrm{Sq} . \mathrm{Km}$. The assessment of surface runoff is much necessary before taking up any kind of conservation measures. The Soil Conservation Services (SCS) method has been employed to assess the surface runoff from the micro watershed. The remote sensing data products has been used to prepare the land use and soil layers. The GIS has been used to integrate the thematic layers to estimate the surface runoff based on $\mathrm{CN}$ values.
\end{abstract}

KEYWORDS : Surface water, Watershed, Geospatial technology,

\section{INTRODUCTION}

The sustainable development has been defined by the World Commission of Environment and Development in 1987 as "development that meets the need of the present without compromising the ability of the feature generations to meet theirneeds"(Pantulu 1996)

Water in its natural hydrological cycle is tapped for human activities from both the surface water and groundwater segments. The ultimate source for all the water is precipitation.

The surface and groundwater are in full form during the monsoon and post monsoon periods and goes on depleting with time due to over exploitation for multifaceted activities. In India the replenishment takes place only during the monsoon and after the monsoon period the stress on the water resources, both on surface and groundwater, is very high. The availability is very low and the demand is high. With the above in mind the sustainability of water resource in particular surface and groundwater has to be analysed on watershed basis using geospatial technology and suggest measures for replenishment.

\section{METHODS OF ACHIEVING SUSTAINABILITY}

The sustainability can be achieved by enforcing a strong and effective monitoring network. An integrated water management system on watershed basis is necessary to attain the sustainability.

Some of the scientific measures to ensure the sustainability are:

w Proper assessment of surface runoff on watershed basis w Delineation of surplus and deficit watershed with respect to surface water.

* Inducing some artificial recharge measures in scientifically identified location.

w Geospatial technology such as, Remote sensing, Geographical Information System and Global Positioning system can be employed to achieve the above.

In the present paper a micro watershed has been taken up to estimate the surface water runoff, using geospatial technology. Kombai micro watershed lies in Vaigai basin. It lies between latitude of $9^{\circ} 43^{\prime}-9^{\circ} 53^{\prime \prime}$ and longitude of $77^{\circ} 12^{\prime \prime}-77^{\circ} 18^{\prime \prime}$. Kombai micro watershed comprises of Uthamapalayam block of Theni district. The aerial extent of the watershed is $64.08 \mathrm{Sq} . \mathrm{Km}$. Of which $46.65 \mathrm{Sq} . \mathrm{Km}$ in plains and $17.43 \mathrm{Sq} . \mathrm{Km}$ in hills (Figure-1)

The main objectives of the study is

* To assess surface water runoff from the micro watershed using SCS Method.

\section{METHODOLOGY}

To achieve the above objective the following methodology has been adopted.

w Demarcation of micro watershed from 1:50000 SOI topo sheet.

* Digitization of micro watershed boundary and other cultural features.

* Digitization of streams according to the stream order.

* Preparation of Land use and Soil map from IRS 1D digital satellite data Using ERDAS Image processing software. 
w Collection and compilation of daily rainfall data.

w Calculation and integration of Land use, Soil map to obtain $\mathrm{CN}$ value use ArcGIS software.

. Estimation of surface runoff for daily, monthly and yearly runoff based on Soil Conservation Services (SCS) method.

The River Suthagangai odai originates from Kambam valley reserved forest area. The drainage pattern of the micro watershed is parallel to sub-parallel and dendritic. Based on Strahler method the drainage morphometric has been done. The drainage map and the stream order are presented in Figure -2

The micro watershed is formed of the Archean crystalline metamorphic complex. The rock types have experienced recurring tectonic and magmatic activities in the Precambrian period, which resulted in the complicated structure and geology. The rock types in the watershed include Granite, Charnockite Garnet biotite gneiss and recent alluvium.

Geomorphology map has been prepared from IRS 1D LISS III digital satellite data using ERDAS Image processing software by hybrid interpretation techniques. Geomorphologically the watershed is comprises of Structural hill, residual hill, linear ridges, shallow pediment, buried pediment, pediment inselberg, bazada, and valley fill. The lineaments act as conduits for groundwater movement. The lineament has been depicted from satellite data.

Slope is one of the important topographical features for determining the infiltration rate and runoff. Based on lan Galbraith (1983) method, the slope has been prepared. The slope elucidates the slope variations in the micro watershed. The digital elevation model is presented in Figure - 5

The micro watershed is covered by four hydrologic soil group such as, A,B,C,D. The soil series includes Palaviduthi, Vylogam, Somayanur and Forest humic. The different soil series and the area of coverage by different soil series are presented in Figure-3

The land use map has been prepared form IRS 1D LISS III digital satellite data. The land use pattern of the micro watershed is presented in Figure-4. Nearly 25 percentage of the area is covered by dry forming.

The occurrence of ground water is restricted to weathered and fractured zone. Detailed geophysical survey and well inventory have been taken up in the micro watershed. The data reveals that the top soil varies from 4 to $8 \mathrm{~m}$ weathering thickness varies from $7 \mathrm{~m}$ to greater than
$22 \mathrm{~m}$ and the fractured zone varies from 8 to $18 \mathrm{~m}$. The weathering thickness ranging from 7 to $12 \mathrm{~m}$ is predominant in the micro watershed. The depth of the dug wells varies form 10 to $25 \mathrm{~m} \mathrm{BGL}$ and the depth of the bore wells varies from 40 to $120 \mathrm{~m}$.

Depth to water level data has been collected for pre and post monsoon seasons in selected wells. The pre monsoon water level varies from $5.5 \mathrm{~m}$ to $8.5 \mathrm{~m}$ and the post monsoon water level ranges from $3.5 \mathrm{~m}$ to $8.5 \mathrm{~m}$. In some places, the water level depleted is below weathered zone.

Groundwater samples from selected number of wells have been collected and tested for physical and chemical quality of water. The quality parameters such as, total dissolved solids, SAR, and sodium percentage have been taken up for the analysis. The quality of groundwater in the study area is generally good.

The nearest raingauge station of the study area is Uthamapalayam. The normal annual rainfall in the micro watershed is $790 \mathrm{~mm}$. The 50 years normal rainfall indicates that the major contribution of rainfall is during north east monsoon, which is $44 \%$ of the total normal rainfall. Daily rainfall data collected from the above rain gauge station have been taken for the analysis and for runoff estimation.

Runoff is one of the most important hydrologic parameter used in most of the water resources applications. The predication of quantity and rate of runoff from the land to the streams is very difficult and it requires more time for ungauged watershed.

Rainfall, if it is not intercepted by vegetation of by artificial surfaces such as roofs or pavements, falls on the earth and either evaporates, infiltrates or lies in depression storage. When the loss arising in these ways are all provided for, there may remain a surplus that, obeying the gravitation laws, flows over the surface to the nearest stream channel. The streams coalesce into rivers and the rivers find their way down to sea.

Runoff may consist of surface runoff, subsurface runoff and groundwater runoff. Surface runoff is that part of runoff which travels over the ground surface and through channels into the basin outlet.

Subsurface runoff (Interflow) is that part of precipitation which infiltrates the surface soil and moves laterally through the upper soil horizons towards the streams.

Groundwater runoff is a portion of groundwater discharged into the streams. 
The surface runoff assessment is very essential to quantify the water that flows out of the watershed. A portion of the surplus flow can be used for conservation with in the watershed.

The conventional methods of predication of runoff requires considerable amount of hydrological and meteorological data. The Remote sensing and GIS can help to a great extent in runoff assessment. Though there are number of methods are available to assess the runoff from a watershed, The Soil Conservation Services (SCS) method has been dealt elaborately, since it is reliable and more accurate than the other methods.

The most generally available data in India are the amounts measured by non-recording rain gauges and for such data, Rainfall-runoff relationship was developed.

Rainfall - runoff relationship, in general form, is given as

$$
\ldots=(p-l a)^{2} /((p-l a)+S)
$$

Where $\ldots=$ actual runoff, $P=$ the rainfall $S=$ potential retention and $\mathrm{la}=$ initial abstraction during the period between the period of beginning of rainfall and runoff in equivalent depth over the Catchment.

The effect of runoff is based on the antecedent soil moisture condition. The Soil Conservation Services has formulated three antecedent soil moisture conditions viz. AMC I, AMC II and AMC III before estimating runoff for a particular rainfall event the curve numbers have to be adjusted according to the season and total 5-day antecedent rainfall.

\section{ANTECEDENT MOISTURE CONDITION (AMC)}

\begin{tabular}{|c|c|c|}
\hline \multirow{2}{*}{ AMC } & \multicolumn{2}{|c|}{ 5 days antecedent rainfall in om } \\
\cline { 2 - 3 } & Dormant season & Growing season \\
\hline I & Less than 1.25 & Less than 3.5 \\
\hline II & 1.25 to 2.75 & 3.5 to 5.25 \\
\hline III & Over 2.75 & Over 5.25 \\
\hline
\end{tabular}

\section{CONDITION OF REGION}

$\begin{array}{ll}\text { Black soil region AMC II and III } & \text { la }=0.1 S \\ \text { Black soil region AMC I } & \text { la }=0.3 S \\ \text { All other regions } & \text { la }=0.3 S\end{array}$

The $S$ values are derived from the Curve Number (CN) values

$$
\begin{aligned}
& \mathrm{CN}=25400 /(254+\mathrm{S}) \\
& \mathrm{S}=(25400 / \mathrm{CN})-254
\end{aligned}
$$

Using the above equations developed are

$\ldots=(P-0.3 S)^{2} /(P+0.7 S) \quad$ _.for all soil regions $\ldots=(\mathrm{P}-0.1 \mathrm{~S})^{2} /(\mathrm{P}+0.9 \mathrm{~S}) \quad$ _.for black soil regions

\section{Runoff curve number for hydrologic soil cover complex}

The Land use pattern of the watershed and the hydrological soil group has to be considered to estimate the Curve number (CN value). The modified curve numbers for AMC-Il are given below in Table - 1. The AMC I \& AMC III have to be taken from the table for the runoff

\begin{tabular}{|c|c|c|c|c|c|c|}
\hline \multirow{2}{*}{ Land use cover } & \multirow{2}{*}{ Treatment of Pratice } & \multirow{2}{*}{$\begin{array}{l}\text { Hydrologic } \\
\text { condition }\end{array}$} & \multicolumn{4}{|c|}{ Hydrologic soil group } \\
\hline & & & A & $\mathrm{B}$ & $\mathrm{C}$ & $\mathrm{D}$ \\
\hline Fallow & Straight row & . & 77 & 86 & 91 & 94 \\
\hline \multirow[t]{6}{*}{ Cullivated } & Straight row & Poor & 72 & 81 & 86 & 81 \\
\hline & Straight row & Good & 67 & 78 & 85 & 89 \\
\hline & Contoured & Poor & 70 & 79 & 84 & 88 \\
\hline & Contoured & Good & 65 & 75 & $\overline{82}$ & 86 \\
\hline & Contoured and teraced & Poor & 66 & 74 & 80 & 82 \\
\hline & Contoured and teraced & Good & 62 & 71 & 78 & 81 \\
\hline \multirow[t]{6}{*}{ Small Grain } & Straight row & Poor & 65 & 76 & 84 & 88 \\
\hline & Straight row & Good & 63 & 75 & 83 & 87 \\
\hline & Contoured & Poor & 63 & 74 & 82 & 85 \\
\hline & Contoured & Good & 61 & 73 & 81 & 84 \\
\hline & Contoured and teraced & Poor & 61 & 72 & $7 \mathrm{c}$ & 82 \\
\hline & Contoured and teraced & Good & 59 & 70 & 78 & 81 \\
\hline \multirow[t]{6}{*}{ Closed seeded } & Straight row & Poor & 66 & 77 & 85 & 89 \\
\hline & Straight row & Good & 58 & 72 & 81 & 85 \\
\hline & Contoured & Poor & 64 & 75 & 83 & 85 \\
\hline & Contoured & Good & 55 & 69 & 78 & 83 \\
\hline & Contoured and teraced & Poor & 63 & 73 & 80 & 83 \\
\hline & Contoured and teraced & Good & 51 & 67 & 76 & 80 \\
\hline \multirow[t]{3}{*}{ Pasture } & & Poor & 68 & 79 & 86 & 89 \\
\hline & & Fair & 49 & 69 & 79 & 84 \\
\hline & & Good & 39 & 61 & 74 & 80 \\
\hline
\end{tabular}
curve numberAMC II.

Table-1. Modified curve numbers for AMC - II

The land use / land cover map has been prepared from IRS 1C LISS III, digital satellite data has been prepared and the area of each land use unit has been calculated and presented in Figure -4

The soil map has been prepared from the satellite data and from the existing soil map of the micro watershed. The soil map and the area of each hydrological soil group is presented in Figure-3

The land use and soil map have been integrated using ArcGIS software and the integrated land use / soil attribute table has been used for the computation of total area weighted curve number of the micro watershed (for AMC II) and from the above table the curve numbers for AMC I and AMC III conditions have been computed. (Figure-5) 
Table-2. Computation of Weighted curve number of Kombai watershed

\begin{tabular}{|c|c|c|c|c|c|c|c|}
\hline SI.No & Landuse & Soil Type & $\begin{array}{l}\text { Area in } \\
\text { Sq.Km }\end{array}$ & $\mathrm{CN}$ & $\%$ Area & $\begin{array}{c}\% \text { AreaX } \\
\text { CN }\end{array}$ & $\begin{array}{l}\text { Weighted CN } \\
\text { of Study Area }\end{array}$ \\
\hline 1 & Built up land & A & 0.76 & 96 & 1.19 & 113.86 & \multirow{22}{*}{$\begin{array}{l}\text { AMC- } \|=76.32 \\
\text { AMC-I }=57.64 \\
\text { AMC- } \|=88.68\end{array}$} \\
\hline 2 & \multirow{4}{*}{ Dry farming } & A & 12.41 & 95 & 19.37 & 1839.81 & \\
\hline 3 & & B & 1.78 & 85 & 2.78 & 236.11 & \\
\hline 4 & & c & 0.35 & 91 & 0.55 & 49.70 & \\
\hline 5 & & D & 0.01 & 95 & 0.02 & 1.48 & \\
\hline 6 & \multirow{4}{*}{ Hills / Barren rocks } & A & 0.25 & 77 & 0.39 & 30.04 & \\
\hline 7 & & B & 0.18 & 86 & 0.28 & 24.16 & \\
\hline 8 & & c & 0.52 & 91 & 0.81 & 73.85 & \\
\hline 9 & & D & 1.04 & 93 & 1.62 & 150.94 & \\
\hline 10 & \multirow{3}{*}{ Irrigated farming } & A & 9.90 & 92 & 15.45 & 1421.35 & \\
\hline 11 & & B & 0.51 & 94 & 0.80 & 74.81 & \\
\hline 12 & & c & 0.06 & 95 & 0.09 & 8.90 & \\
\hline 13 & \multirow{3}{*}{ Land with scrub } & A & 1.31 & 33 & 2.04 & 67.46 & \\
\hline 14 & & B & 4.53 & 47 & 7.07 & 332.26 & \\
\hline 15 & & c & 0.52 & 64 & 0.81 & 51.94 & \\
\hline 16 & \multirow{3}{*}{ Less erosion } & A & 0.93 & 71 & 1.45 & 103.04 & \\
\hline 17 & & B & 3.74 & 80 & 5.84 & 466.92 & \\
\hline 18 & & $\mathrm{C}$ & 0.01 & 85 & 0.02 & 1.33 & \\
\hline 19 & \multirow{4}{*}{ Severe erosion } & A & 1.82 & 68 & 2.84 & 193.13 & \\
\hline 20 & & B & 5.86 & 71 & 9.14 & 649.28 & \\
\hline 21 & & C & 0.19 & 78 & 0.30 & 23.13 & \\
\hline 22 & & D & 0.04 & 84 & 0.06 & 5.24 & \\
\hline
\end{tabular}

The daily rainfall data of Uthamapalayam rain gauge station has been collected for the year 1990 and 2004 and the weighted curve number of the micro watershed has been given as input for the calculation of daily runoff. The daily runoff of the micro watershed for the year 1990 and 2004 is presented as tables (Table 1\&2). The monthly runoff is presented below.

Table-3. Monthly Runoff Estimation for the year 1990 \& 2004

\begin{tabular}{|c|c|c|c|c|c|c|}
\hline & \multicolumn{3}{|c|}{1990} & \multicolumn{3}{c|}{2004} \\
\hline Month & $\begin{array}{c}\text { Rainfall } \\
\text { in mm }\end{array}$ & $\begin{array}{c}\text { Runoff } \\
\text { in mm }\end{array}$ & $\begin{array}{c}\text { Runoff } \\
\text { in MCM }\end{array}$ & $\begin{array}{c}\text { Rainfall } \\
\text { in mm }\end{array}$ & $\begin{array}{c}\text { Runoff } \\
\text { in mm }\end{array}$ & $\begin{array}{c}\text { Runoff } \\
\text { in MCM }\end{array}$ \\
\hline January & & & & 102.40 & 70.52 & 4.52 \\
\hline February & & & & & & \\
\hline March & & & & 30.70 & 2.54 & 0.16 \\
\hline April & & & & & & \\
\hline May & 170.00 & 84.85 & 5.44 & 36.00 & & \\
\hline June & 110.00 & 71.79 & 4.60 & & & \\
\hline July & 20.00 & & & 42.80 & 2.30 & 0.15 \\
\hline August & & & & 75.80 & 26.65 & 1.71 \\
\hline September & 230.00 & 29.27 & 1.88 & 184.60 & 66.27 & 4.25 \\
\hline October & 158.00 & 2.75 & 0.18 & 127.60 & 21.81 & 1.40 \\
\hline November & 130.00 & 14.56 & 0.93 & 84.60 & 2.62 & 0.17 \\
\hline December & 4.00 & & & 14.60 & & \\
\hline Total & 822.00 & 203.22 & 13.02 & 699.10 & 192.71 & 12.35 \\
\hline
\end{tabular}

The runoff estimation using SCS method reveals that there is sufficient runoff potential is available in the Kombai micro watershed. A portion of the runoff can be used for conservation measures in the micro watershed for sustainable groundwater development.

\section{CONCLUSION}

- As far as the Kombai micro watershed is concerned, the surface water runoff is considerably good and the groundwater resources is very less (Over exploited), which requires more attention to improve the groundwater resources.

$\checkmark$ Conclusively, the integrated watershed approach is essential for assessing the surface runoff, groundwater potential and for identifying artificial recharge potential zones.

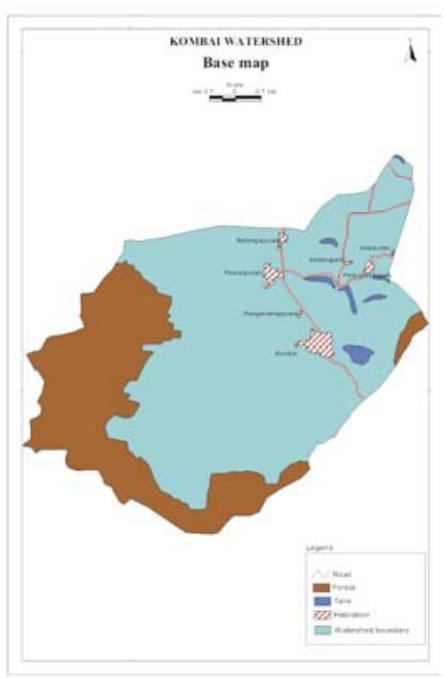

Fig .1 Kombai Watershed Base map

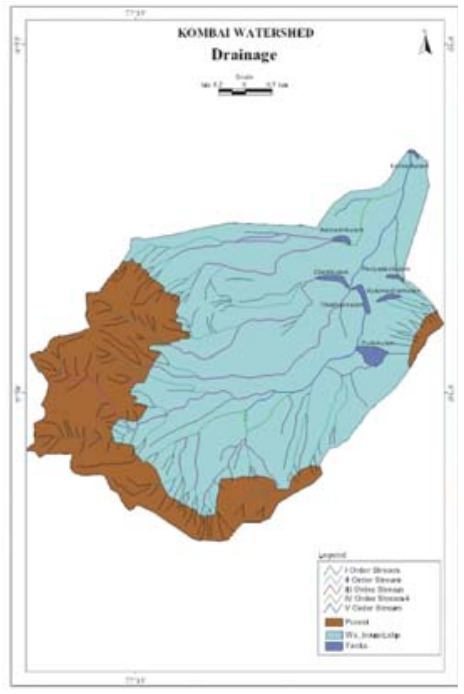

Fig .2 Kombai Watershed Drainage 


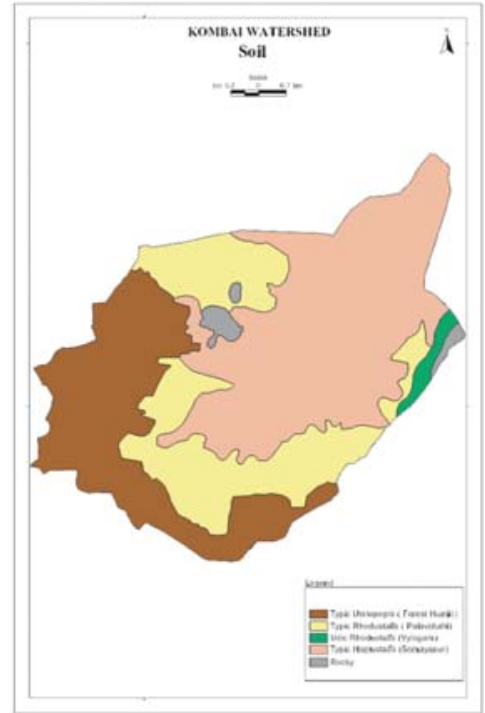

Fig .3 Kombai Watershed Soil

Table-4. Area Coverage

\begin{tabular}{|l|c|c|}
\hline Soil & $\begin{array}{c}\text { Area } \\
\text { in Sq.Km }\end{array}$ & $\begin{array}{c}\text { Area } \\
\text { in Ha }\end{array}$ \\
\hline Rocky & 1.09 & 109 \\
\hline $\begin{array}{l}\text { Typic } \\
\text { Haplustalfs }\end{array}$ & 27.96 & 2796 \\
\hline $\begin{array}{l}\text { Typic } \\
\text { Rhodustalfs }\end{array}$ & 16.74 & 1674 \\
\hline $\begin{array}{l}\text { Typic } \\
\text { Urstopepts }\end{array}$ & 17.43 & 1743 \\
\hline $\begin{array}{l}\text { Udic } \\
\text { Rhodustalfs }\end{array}$ & 0.86 & 86 \\
\hline Total & $\mathbf{6 4 . 0 8}$ & 6408 \\
\hline
\end{tabular}

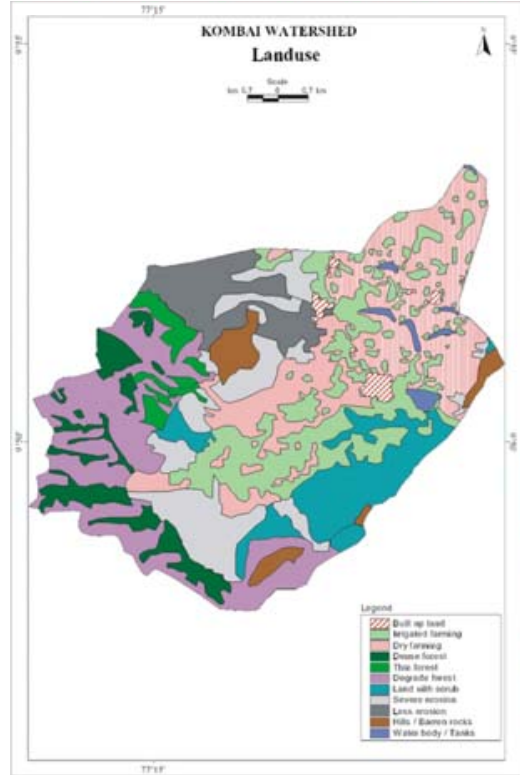

Fig .4 Kombai Watershed Landuse
Table-5. Area Covered for different landuse pattern

\begin{tabular}{|l|c|c|r|}
\hline & $\begin{array}{c}\text { Area } \\
\text { in } \\
\text { Sq.Km }\end{array}$ & Area in Ha & Area \% \\
\hline Built up land & 0.77 & 77 & 1.20 \\
\hline Degrade forest & 10.92 & 1092 & 17.04 \\
\hline Dense forest & 4.16 & 416 & 6.49 \\
\hline Dry farming & 14.51 & 1451 & 22.64 \\
\hline $\begin{array}{l}\text { Hills / Barren } \\
\text { rocks }\end{array}$ & 1.98 & 198 & 3.09 \\
\hline Irrigated farming & 10.43 & 1043 & 16.28 \\
\hline Land with scrub & 6.40 & 640 & 9.99 \\
\hline Less erosion & 4.62 & 462 & 7.21 \\
\hline Severe erosion & 7.92 & 792 & 12.36 \\
\hline Thin forest & 1.72 & 172 & 2.68 \\
\hline $\begin{array}{l}\text { Water body / } \\
\text { Tanks }\end{array}$ & 0.65 & 65 & 1.01 \\
\hline & & & \\
\hline Total & 64.08 & 6408 & \\
\hline
\end{tabular}

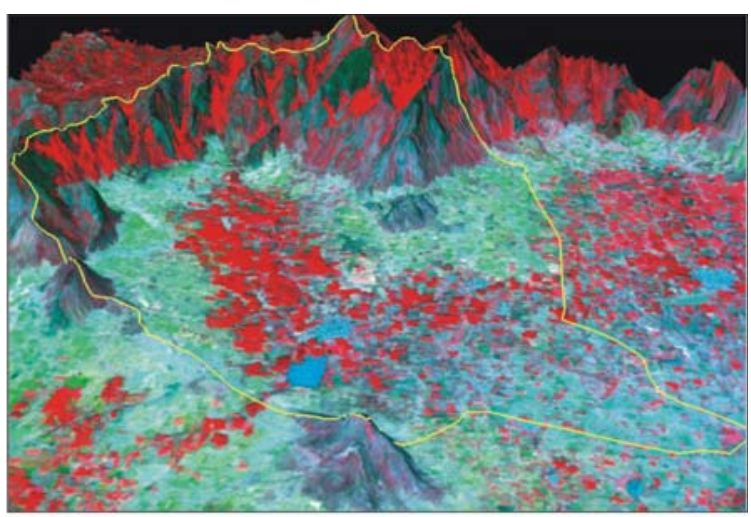

Fig .5 - Digital terrain model of Kombai micro watershed

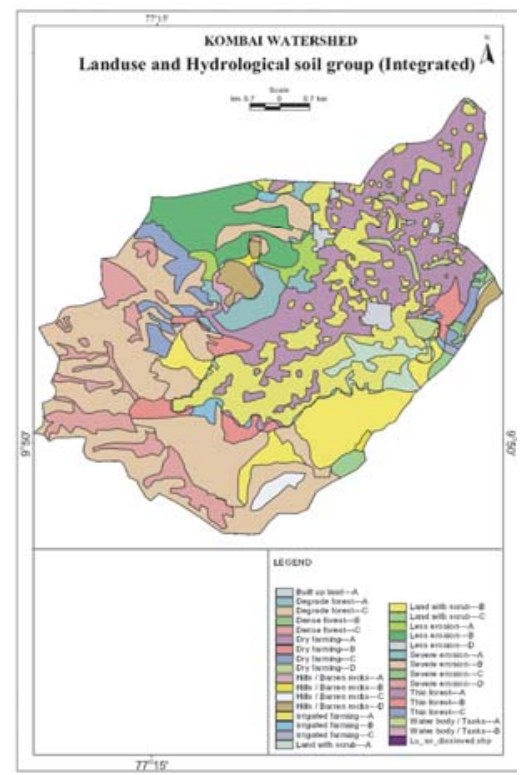

Fig . 6 Kombai Watershed Landuse and Hydrological soil group (Integrated) 


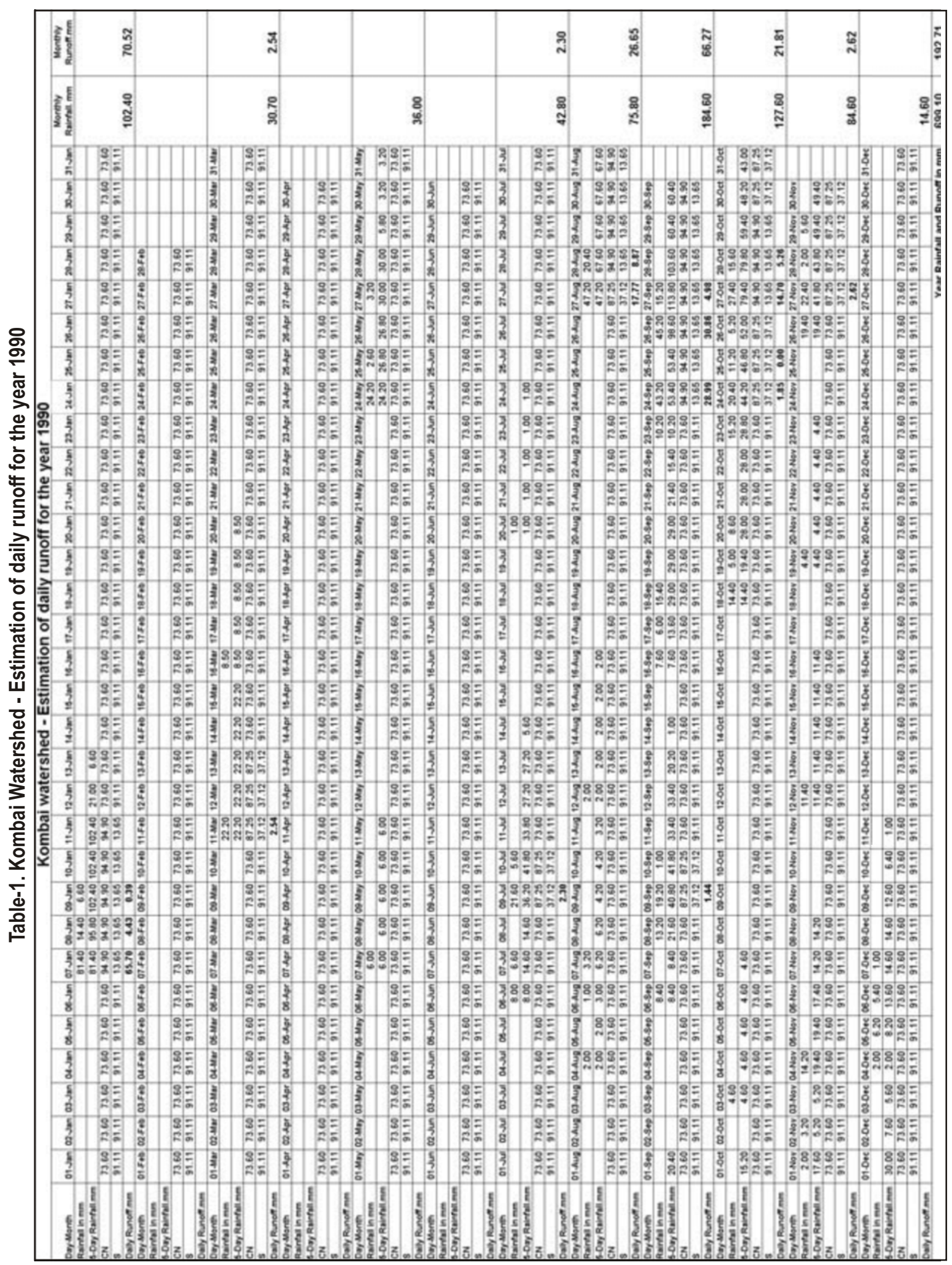




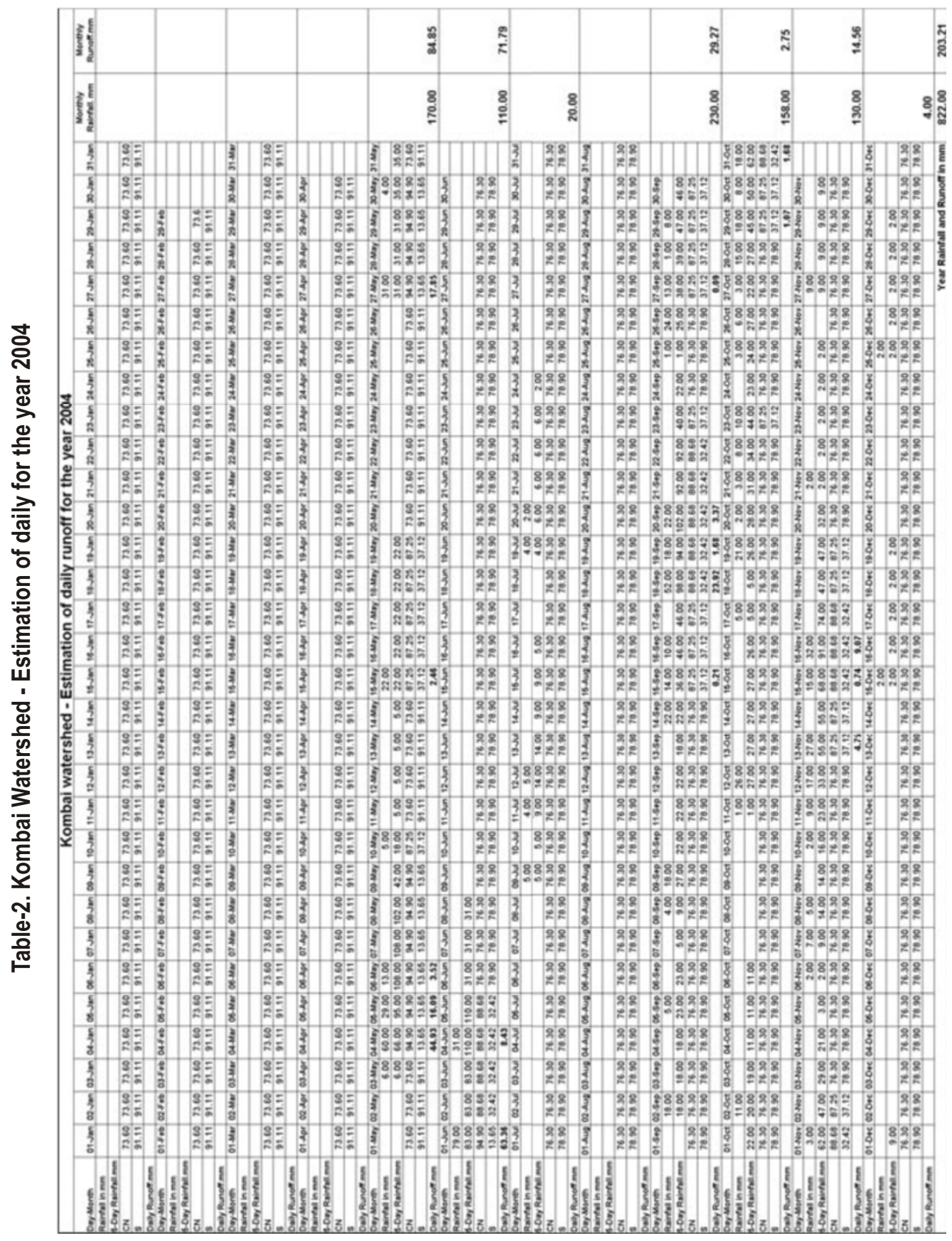

REFERENCES

[1] David Keith Todd, 1976 Ground water Hydrology

[2] Wilson,E.M. 1990 Engineering Hydrology

[3] CGWB, 1994 Manual on Artificial recharge of ground water

[4] Gurmel Singh etal., 1990 Manual of Soil \& water conservation practices

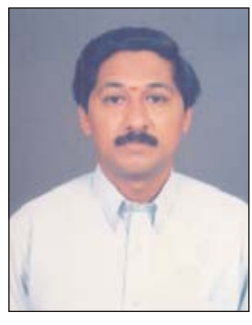

Mr. Ramasubramaniam .K is a Research Scholar in the University of Madras. He has worked in various capacities related to Environmental Engineering and is he is actively working in fields of Environmental Impact Assessment and Air quality modeling. 